\title{
Property Management Services of Different Village Clubhouses: Basis for an Improved Quality Model
}

\author{
Rosario B. Gumban ${ }^{a}$,Jessie Anne T. Demetillo ${ }^{b}$, Liane Vina G. Ocampo \\ a,b,c cavite State University \\ a rbgumban@cvsu.edu.ph, bitdemetillo@cvsu.edu.ph, ${ }^{c}$ lianeocampo@cvsu.edu.ph
}

Article History: Received: 10 November 2020; Revised 12 January 2021 Accepted: 27 January 2021; Published online: 5 April 2021

\begin{abstract}
The study aims to assess the property management services of Village Clubhouses as the basis for an improved quality management model. It sought to establish the profile of the customers that will represent the sample in the study, that helped identify the level of perception and compare the results to the level of expectation and the gaps of service quality using the SERVQUAL framework. The study determined the significant difference between the level of expectation and level of perception of service quality, respectively.

The result showed that the level of perception was low and that expectations were not met after the service have been experienced. The levels of perception vary based on their interest, the number of usages, and the facility being used; and the level of perception changes over time. The current findings call for emergent attention from the property management services company to take appropriate service performance and physical resource structure and monitor such to improve service quality to customers and employee performance.
\end{abstract}

Keywords: property management, quality management, service quality, Village Clubhouses.

\section{Background, Motivation, and Objectives}

Presidential Decree No. 1216 is one of the real estate laws in the Philippines that requires owners or developers of land to provide "open spaces" intended for developing recreational facilities and amenities for private and public use.

The development of the community facilities and amenities is not only for the marketability of the real estate property but also to accentuate the quality of life of the "members".

Initially, the maintenance and security of open spaces is the sole responsibility of the real estate owners or developers. Though association dues are being collected from the members after purchasing the property, operating expenses in the maintenance of the property of the real estate owners or developers grow overtime. Managing these properties properly poses various challenges and becomes more accessible for things to fall through the cracks (Muela, J., 2018).

Conversely, good property management reduces operating expenses, and a desirable ambience is maintained, which adds to the property's profitability (Business Coach, Inc., 2018). It also adds value to older and more dilapidated properties. (Monkkonen, P. and Li, J. 2014).

Excellent property management reflects the environment of social governance and improves residents' satisfaction rate. (Yang, H., 2020)

Mostly, real estate companies in the Philippines organize their property management subsidiaries. But some are sourcing out services from property management companies which they believe lessens the burden within. Using a professional property management company has several benefits and saves money. (Berkompas, C., 2018).

On the other hand, high-quality customer service of property managers adds significant value to real estate portfolios. (Sanderson, D.C., and Read, D. C., 2020).

Growth is an indicator that the company is doing well and with an added solidity. And quality is one of the intervening factors of development. Nevertheless, more often, quality is sacrificed for the sake of growth.

Quality has become one of the most critical aspects of deciding what to choose and buy among competing products and services. But this also affects customer perception and enhances it (Belyh, A. 2018). 
The word quality varies and can be defined in different and many ways. To one, quality is meeting and in conformance to requirements. For others, it is fitness for use. Perfectionists define it as being defect-free or perfect. In business, quality could mean as it is better than competitors.

Customers' concept of quality is relating to the desirable characteristics possessed by the product or service from its rival; exceeding their expectations.

Business success, growth, and competitiveness are the result of how companies understand and improved quality (Montgomery, et al. 2012).

Property Management, as defined by Business Dictionary, is the managing process of property available for leasing, its maintenance, and the day-to-day operational management of the real estate. It also includes but is not limited to seeking out tenants, collection of payments, and upkeep of the grounds.

Maximization of income and lessen the number of expenses is the primary goal of property management services (Real Property Management, 2018).

Land and buildings are part of the success of the operation of organizations/institutions, both public and private. This success depends on the efficiency and effectiveness of property management (Mohammad, M. I., Musa, S.I., and Bello, T.H. 2013).

Maintenance and prolonged operation rely on its usage and profitability. Usage is dependent on satisfaction and preferences.

Besides a question is being asked if the product or service delivered meet as expected. And does it fulfil the customers' needs? The whole process of interaction involved is crucial and essential.

Customer perception varies and is dynamic. The perception towards the organization and product or service offerings changes with the developing relationship between them. As the customer accumulates experiences, perceptions change from fact-based judgments to a more general meaning. Over time, customer needs and preferences change towards certain circumstances.

In the external environment, competitors offering the best of their products or services alter customers' perceptions. Public opinion on specific issues changes by mere comparison.

Research has been done about the perception of product quality and its impact on market share. Customer perception focuses on individual customers but does apply to business to business (B2B) situations. A good instrument is needed in managing customer perceptions, i.e. through market research and surveys (Recklies, D. 2015).

The most challenging part of property management of real estate assets does not only hold on to the idea, if it is outsourced nor in-house, or somewhat pay attention to the demand level of its customers but also the management of quality of the property being offered. The reason why this study is being conducted is to assess the property management services, elevate concerns to help property managers identify what matters most, and then develop a magnitude of service quality ensuing business accomplishments.

\section{Statement Of Contribution}

The understanding of different customers' behaviour of village clubhouses is important for the formulation of strategies and policies and proper management.

From the overall description of the assessed service quality of property management of a real estate company, it is then identified that a gap exists between customers' expectations and perceptions that contribute to the idea in the formulation of a quality management model for property management of the village clubhouses. The arrived model in this paper does not homogenously generalize the proposition of application across the management of the property but only will guide them in the application of appropriate service performance, and appropriate physical resource structure and monitoring of such is essential. It may offer a conceptual framework for quality property management services.

The challenge still to the real estate owners or developers is not only the quality of service being offered but also how to properly upkeep the facilities to achieve the desired level of perception, maintain the relationship, and exercise of service consistency to come up profitable and demandable. 


\section{Methods}

The study used the SERVQUAL survey questionnaire formulated by A. Parasuman et al. (1985, 1988) for the gathering and collection of data as it is the most common method. It is a consistent, acceptable approach in measuring service quality concept (Mohammad, M. I., Gambo, Y. L., and Omirin, M. M. 2012).

The service quality model is viewed as:

Service Quality $(\mathrm{Q})=$ Perception $(\mathrm{P})$ - Expectation $(\mathrm{E})$

Perceived service quality (Q) is the result of variance in the ratings of customer's perception (P) and expectation (E) statements (Parasuraman, A., Zeithaml, V. A., \& Berry, L. L. (1988). The medium is made up of matched pairs of questions; 22 items in each category, i. e. expectation and perception. Five quality dimensions are aligned to assess the customer's chain of thoughts of quality of service of the property management. The tangibility quality dimensions comprise of four items that help describe the appearance of physical facilities of the village clubhouses, its equipment, personnel on-site, and communication materials used. Reliability, on the other hand, has five items that include the capacity to do the promised service with accuracy and dependability. And another four items about responsiveness that concerns the willingness to help and provide prompt customers' service. Four items for assurance, which is about knowledge and courteousness of employees and the ability to carry trust and have confidence; and the other five items towards empathy that is about the care and individual attention property management provides its customers. The participants of the study were customers who have confirmed reservations and experienced the service of the property management company. The first 20 customers were chosen to meet the set quota/number regardless of its status, i. e., membership and classification, as well as facilities used, either first-timers or repeat customers, to participate in the said survey. Retrieved 240 questionnaires and are then used in the analysis.

\section{Results And Discussions}

In an industry where service is the product itself, continuous assessment and development are necessary. Meeting customers' expectations is no easy job. Numerous strategies are created to suit customers' expectations, but not all of those were met and even though they are it differs. The level of service quality as to expectation should always be identified and hear customer's perception to identify gaps, if it is favourable or not, to create a plan of action. In this case, the level of perception is lower than the level of expectation, as shown in Table I. Management needs to see the difference between and address issues promptly.

The assessed level of service quality offered by village clubhouses is a representation of how they manage the property and the kind of service they are offering. It seems that the organization is facing pressures from the demand of its customers, but there appeared to be no well-defined measures of how to convene strategies to address the issue.

Table I. Test of difference between the respondents' expected and perceived levels of quality of the property management services

\begin{tabular}{|l|l|l|l|}
\hline Variable & Mean & SD & $\begin{array}{l}\text { Mean } \\
\text { Difference }\end{array}$ \\
\hline $\begin{array}{l}\text { Expected Level of } \\
\text { Quality }\end{array}$ & 4.1049 & 0.848 & $1.74321^{\text {hs }}$ \\
\hline $\begin{array}{l}\text { Perceived Level of } \\
\text { Quality }\end{array}$ & 2.3617 & 0.924 & \\
\hline
\end{tabular}

Table II. Frequency distribution table of the respondents' membership status

\begin{tabular}{|c|c|c|}
\hline Membership Status & Frequency & Percent \\
\hline Lot Owner & 60 & $25.0 \%$ \\
\hline Homeowner & 60 & $25.0 \%$ \\
\hline Employee & 13 & $5.4 \%$ \\
\hline Shareholder/Affiliates & 4 & $1.7 \%$ \\
\hline Non-member & 103 & $42.9 \%$ \\
\hline Total & $\mathbf{2 4 0}$ & $\mathbf{1 0 0 . 0 \%}$ \\
\hline
\end{tabular}

Most of the respondents are non-members. The result in Table II shows that it is highly significant between the level of expectation and level of perception as to profile consideration and dimension. Lot owners and homeowners have a probability of influencing the level of perception combining ratings of both with a total of $50 \%$. The level of perception among the lot owners', homeowners, and non-members have significant differences. 
It could suggest that the rating from these classes affects the idea of what quality of property management services are experienced and should have had because of the importance of village clubhouses facilities to them.

Table III below express the idea that families used the village clubhouses frequently with a $43.8 \%$ rate. It signifies that the place is enjoyed among any age group composed of this group category. Even though educational institutions are the least group of people come to the village clubhouses to avail the facilities being offered, results across categories still have a highly significant difference in the level of perception. It could be an implication that these perceptions are in contrast because of the needed requirements.

On the contrary, it has been observed that most visitors have been to the clubhouse 2 to 3 times, as presented in Table IV below. Conversely, a group of people who visits the village clubhouse for the first time have different expectations compared to those who have been for 4 to 5 times, 6 to 7 times, and more than eight times of visits. More than eight times users have a significant difference in the level of perception compare to 4 to 5 times and 6 to 7 times users; an indication that overtime; expectations change so consistency and variance of service offerings should be adopted.

Moreover, the swimming pool is the most used facility in the village clubhouses with $36.7 \%$ as shown in Table V. This suggests that proper maintenance and service of the swimming pool are highly needed while the picnic area has a minimum requirement. Statistics also prove that the level of perception of people who uses the picnic area has a significant difference from those who manage to book the swimming pool, main hall, and basketball, tennis, and badminton courts.

Table III. Frequency distribution table of the respondents'classification status

\begin{tabular}{|c|c|c|}
\hline Classification Status & Frequency & Percent \\
\hline Family & 105 & $43.8 \%$ \\
\hline Group & 68 & $28.3 \%$ \\
\hline Educational Institution & 32 & $13.3 \%$ \\
\hline Organization & 35 & $14.6 \%$ \\
\hline Total & $\mathbf{2 4 0}$ & $\mathbf{1 0 0 . 0 \%}$ \\
\hline
\end{tabular}

Table IV. Frequency distribution table of the respondents'number of usage

\begin{tabular}{|c|c|c|}
\hline Number of Usage & Frequency & Percent \\
\hline 0 to 1 time & 77 & $32.1 \%$ \\
\hline 2 to 3 times & 95 & $39.6 \%$ \\
\hline 4 to 5 times & 36 & $15.0 \%$ \\
\hline 6 to 7 times & 14 & $5.8 \%$ \\
\hline 8 times and more & 18 & $7.5 \%$ \\
\hline Total & $\mathbf{2 4 0}$ & $\mathbf{1 0 0 . 0 \%}$ \\
\hline
\end{tabular}

Table V. Frequency distribution table of the respondents'facility usage

\begin{tabular}{|c|c|c|}
\hline Facility Used & Frequency & Percent \\
\hline Main Hall & 71 & $29.6 \%$ \\
\hline Swimming Pool & 88 & $36.7 \%$ \\
\hline Pool Side & 13 & $5.4 \%$ \\
\hline Picnic Area & 15 & $6.3 \%$ \\
\hline Basketball Court & 31 & $12.9 \%$ \\
\hline Tennis Court & 12 & $5.0 \%$ \\
\hline Badminton Court & 8 & $3.3 \%$ \\
\hline Others & 2 & $0.8 \%$ \\
\hline Total & $\mathbf{2 4 0}$ & $\mathbf{1 0 0 . 0 \%}$ \\
\hline
\end{tabular}

Seeing the results of the comparative analysis between the level of expectation in Table VI and the level of perception in Table VII, all variables have significant influences in determining the level of service quality.

The outcome of the survey is a signal that real estate owners or developer must ensure that key performance indicators (KPIs) are in place. And appropriate incentives to employees are taken into consideration to ensure that property management services deliver a professional service (Sanderson, D. C., and Edwards, V. M. 2016). 
Employee engagement should be considered as this can significantly improve company performance across several key areas such as profitability, productivity, customer satisfaction, innovation, health and safety, sickness and absence, turnover, and wellbeing. (Clapton, P., 2014).

It is not possible to measure property management service quality directly. Instead, quality must be inferred from the recipient's assessment. However, the recipients are not homogeneous, the service itself is not necessarily consistent, and opinions differ. The characteristics of service are widely acknowledged that includes "intangibility-the relative inseparability of production and consumption, and relative heterogeneity under involving the interaction of service personnel and customers, making each instance of service different" (Sanderson, D. C., and Edwards, V. M., 2016).

Table VI. Comparative analysis between the expected levelof quality of property management services

\begin{tabular}{|l|l|l|l|l|l|}
\hline Variable & $\begin{array}{l}\text { F- } \\
\text { statistic }\end{array}$ & Df1 & Df2 & $\begin{array}{l}\text { p- } \\
\text { value }\end{array}$ & Remarks \\
\hline $\begin{array}{l}\text { Membership } \\
\text { Status }\end{array}$ & 3.101 & 4 & 20.079 & 0.039 & Significant \\
\hline $\begin{array}{l}\text { Classification } \\
\text { Status }\end{array}$ & 4.210 & 3 & 100.007 & 0.008 & $\begin{array}{l}\text { Highly } \\
\text { Significant }\end{array}$ \\
\hline $\begin{array}{l}\text { Number of } \\
\text { Visits }\end{array}$ & 6.741 & 4 & 71.979 & $\begin{array}{l}\text { P } \\
0.01\end{array}$ & $\begin{array}{l}\text { Highly } \\
\text { Significant }\end{array}$ \\
\hline $\begin{array}{l}\text { Facilities } \\
\text { Used }\end{array}$ & 7.855 & 7 & 16.272 & $\begin{array}{l}\text { P } \\
0.01\end{array}$ & $\begin{array}{l}\text { Highly } \\
\text { Significant }\end{array}$ \\
\hline
\end{tabular}

Table VII. Comparative analysis between the perceivedlevel of quality of property management services

\begin{tabular}{|l|l|l|l|l|l|}
\hline Variable & $\begin{array}{l}\text { F- } \\
\text { statistic }\end{array}$ & Df1 & Df2 & $\begin{array}{l}\text { p- } \\
\text { value }\end{array}$ & Remarks \\
\hline $\begin{array}{l}\text { Membership } \\
\text { Status }\end{array}$ & 6.183 & 4 & 20.946 & 0.002 & $\begin{array}{l}\text { Highly } \\
\text { Significant }\end{array}$ \\
\hline $\begin{array}{l}\text { Classification } \\
\text { Status }\end{array}$ & 10.767 & 3 & 100.151 & $\begin{array}{l}\text { P } \\
0.01\end{array}$ & $\begin{array}{l}\text { Highly } \\
\text { Significant }\end{array}$ \\
\hline $\begin{array}{l}\text { Number of } \\
\text { Visits }\end{array}$ & 2.889 & 4 & 54.513 & 0.031 & Significant \\
\hline Facilities Used & 8.129 & 7 & 16.718 & $\begin{array}{l}\text { P } \\
0.01\end{array}$ & $\begin{array}{l}\text { Highly } \\
\text { Significant }\end{array}$ \\
\hline
\end{tabular}

From a service perspective, reliability and responsiveness were found the essential quality dimension for customers. In this study, assurance is the number one salient factor among the other indicators, see in Table VIII.

Like empathy, the extent to which a customer feels, "assurance" depends upon the professionalism of the owner and service provider, and encompasses trust and reassurance. Property Management has always been a people profession, where success is predicated on building long-term relationships, trust, and assurance. (Palm, P., 2015). Furthermore, maintenance is something that must be addressed and taken care of; otherwise, it will the company's demise (Rozenberg, S. and Tepman, M.L. 2020). Since results indicate that tangibility is also highly significant, other quality dimensions lighted to the idea that the service quality of the property management of the real estate company needs urgent attention.

Even though the SERVQUAL model was adapted in the assessment of customers' expectations and perceptions, the researchers still find it necessary to develop a quality model specifically designed for the property management service of the village clubhouse to consider.

The SERVQUAL model was modified with an addition of appropriate service performance and appropriate physical resources in the proposed property management quality model, as seen in Fig. 1.

The proposed property management quality framework is the understanding of its nature and strains of the property management services requirement of these village clubhouses, where service and the real estate assets are vital. It also illustrates that the process will continue after the perceived service quality is addressed by monitoring the service performance and physical resource structure development

through feedbacks. Service quality indeed influences long-term relationships (Venetis, K. \& Ghauri, P. 2014) and customer engagement.

The real estate properties value contribution can be optimized when the property personnel in-charge performs continuous application of appropriate capability as a pre-requisite in the property/facilities management being the custodian and enabler of the corporate workplace environment (Then, D. S. S. 2005). 
Customer service and overall customer experience is easy to understand and straight forward to gauge (Swinscoe, A. 2016). Thus, underestimating customer service and disengaging customer perception could result in unsatisfied customers and in return, leave negative reviews and lead to customer churn (Bernazzani, S. 2018).

Udemy.com describes the process of managing the quality of services delivered to a customer according to his expectations is called service quality management, and assessing the given service to improve quality, identify problems and correct them increase customer satisfaction.

Whilst service quality management, the property management industry needs to regularly evaluate performance because the lack of a unified standard for talents is an addition to problems in the skills selection (Yu, Z. 2011) and performance management.

Table VIII. Summary of the mean difference of perception vs expectation

\begin{tabular}{|l|c|c|c|c|c|c|}
\hline \multicolumn{1}{|c|}{$\begin{array}{c}\text { Quality } \\
\text { Dimension }\end{array}$} & $\begin{array}{c}\text { Mean } \\
\text { Score } \\
\text { (Perception) }\end{array}$ & $\begin{array}{c}\text { Mean } \\
\text { Score } \\
\text { (Expectation) }\end{array}$ & $\begin{array}{c}\text { Mean } \\
\text { Difference }\end{array}$ & $\begin{array}{c}\text { t- } \\
\text { statistic }\end{array}$ & $\begin{array}{c}\mathrm{p}- \\
\text { value }\end{array}$ & Significance \\
\hline Tangibility & 2.2594 & 4.0385 & -1.77917 & -19.507 & $\mathrm{p}<0.01$ & Highly Significant \\
\hline Reliability & 2.3375 & 4.1175 & -1.78000 & -17.141 & $\mathrm{p}<0.01$ & Highly Significant \\
\hline Assurance & 2.4375 & 4.1813 & -1.74375 & -16.552 & $\mathrm{p}<0.01$ & Highly Significant \\
\hline Empathy & 2.3992 & 4.0675 & -1.66833 & -15.109 & $\mathrm{p}<0.01$ & Highly Significant \\
\hline Responsiveness & 2.3750 & 4.1198 & -1.74479 & -16.343 & $\mathrm{p}<0.01$ & Highly Significant \\
\hline
\end{tabular}

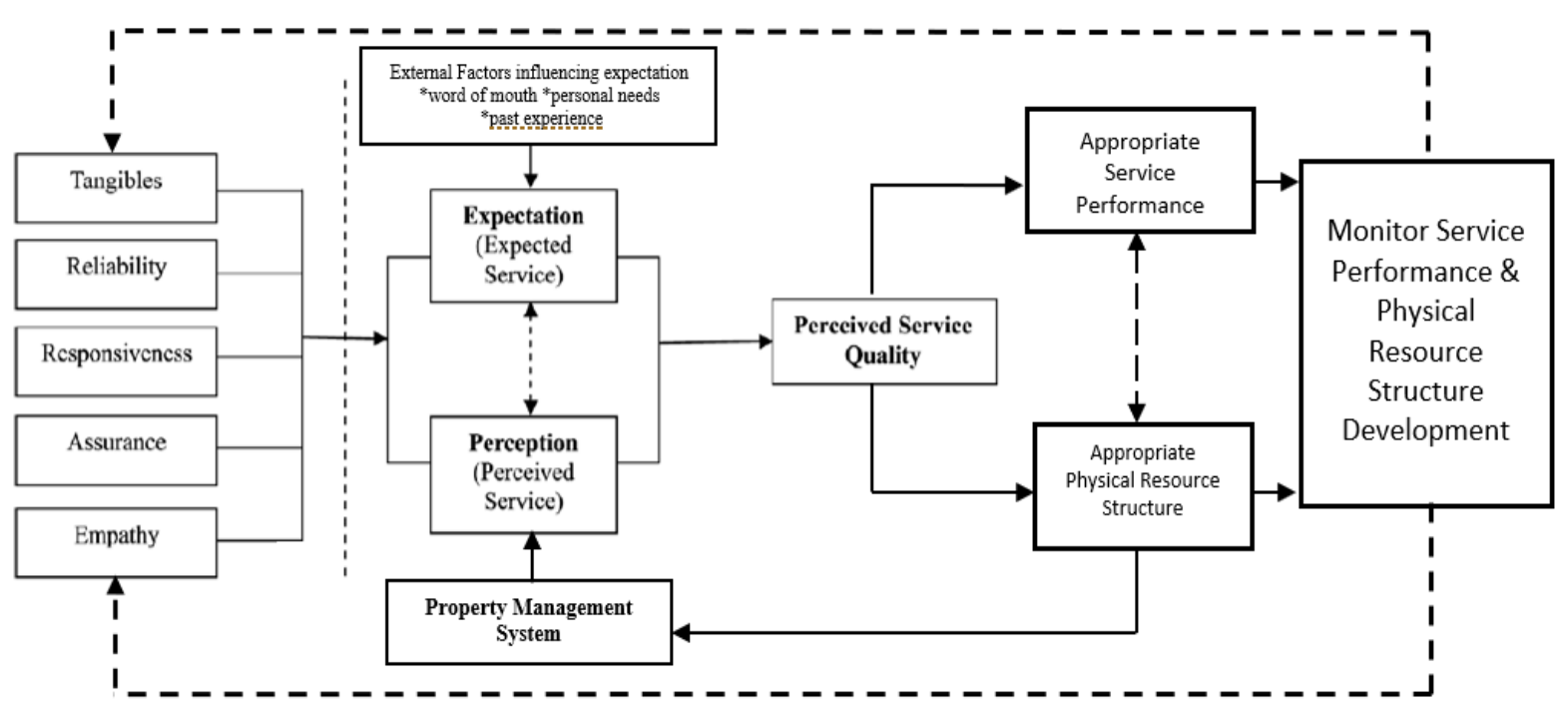

Fig. 1. Proposed Property Management Quality Model

\section{Conclusion}

The use of SERVQUAL in determining the level of expectation and level of perception of customers of the property management of the real estate company assess the quality level of the service being offered. Relative to that, it was found out that all quality dimensions have high gap scores reflecting low service quality.

But, notably, most of the customers of these village clubhouses are non-members. It would mean that this group of people is a potential market to engage. And since reliability has the highest mean difference, real estate property owners or developers should check the condition of the facilities used, the serviceability, functionality, the safety of the structure and the grounds.

Another prominent concern is the reliability among quality dimensions. It seems that customers compare past service offerings if we are to see that most of them have previous experiences, used the facilities available 2 to 3 times. With this, key personnel of the property management should have competencies level in remembering frequent or regular customers and deliver consistent, if not better, quality service offerings from previous experiences in the village clubhouses.

The identification of the level of service quality of property management adopting the SERVQUAL model is a helpful tool for quality management. However, the application of appropriate service performance and physical resource structure will initially resolve issues as the results suggest. That is, a new property management quality 
model is formulated to transcribe the initial concept on how to fill the gaps. Besides, the application of closely monitoring the quality of service and property being used is a must and a continues process.

\section{References}

A. Belyh. Perception, Cleverism. Retrieved from https://www.cleverism.com/lexicon/customer-perception/, December 2017.

C. Berkompas. Benefits of Using A Property Management Company. Retrieved from https://www.managemyproperty.com/articles/benefits-of-using-a-property-management-company-136, 20092020.

S. Bernazzani. Hubspot. What is Customer Satisfaction. Retrieved from https://blog.hubspot.com/service/whatis-customer-satisfaction, May 2018.

BusinessCoach, Inc. Building and Property Management. Retrieved from http://www.businesscoachphil.com/building-and-property-management, (2018).

Business Dictionary, (2018). Retrieved from http://www.businessdictionary.com/definition/propertymanagement.html.

P. Clapton. Employee Engagement. Retrieved from https://gethppy.com/employee-engagement/15-employeeengagement-activities-can-start-now, July 2014.

J. Li and P. Monkkonen, "The value of property management services: an experiment", Property Management, Emerald Insight Vol. 32 No. 3, pp. 213-223. https://doi.org/10.1108/PM-06-2013-0035, June 2014.

D. Montgomery, C. Jennings, and M. Pfund. Managing, Controlling, and Improving Quality. Library of Congress Cataloging-in-Publication Data, Wiley \& Sons, Inc., NJ, 2012.

M. I. Mohammad, Y. L. Gambo, and M. M. Omirin. Assessing Facilities Management Service in Postgraduate Hostel Using Servqual Technique, Journal of Emerging Trends in Economics and Management Sciences (JETEMS) 3(5): 485-490. Retrieved from https://www.researchgate.net/publication/263748082, June 2012.

M. I. Mohammad, S.I. Musa and T.H. Bello. Quality of Property Management Service in Public Educational Buildings in Nigeria, Mediterranean Journal of Social Sciences, Published by MCSER-CEMAS-Sapienza University of Rome Vol 4 No 2 May 2013. Retrieved from https://www.researchgate.net/publication/263747586_Quality_of_Property_Management_Service_in_Public_ Educational_Buildings_in_Nigeria?enrichId=rgreq-179bd590b737b6dd8d83ff70b9f62166-

XXX\&enrichSource=Y292ZXJQYWdlOzI2Mzc0NzU4NjtBUzo1NzU2MjcwOTY0MDgwNjRAMTUxNDI 1MTYwMjc2Mg\%3D\%3D\&el=1_x_2\&_esc=publicationCoverPdf, May 2013.

J. Muela. Property Management Services - A Complete List and 11 Questions for Determining if You Need a Property Management Firm. Retrieved from https://www.managemyproperty.com/articles/propertymanagement-services-a-complete-list-7; https://www.managemyproperty.com/articles/11-questions-fordetermining-if-you-need-a-property-management-firm-8, 2020.

P. Palm. Challenges of Commercial Real Estate Management: An analysis of the Swedish commercial real estate industry. 10.13140/RG.2.1.1290.0564. Retrieved from https://www.researchgate.net/publication/283044327, October 2015.

A. Parasuraman, V. Zeithaml, and B. Leonard. A Conceptual Model of Service Quality and its Implication for Future Research (SERVQUAL). The Journal of Marketing. 49. 41-50. 10.2307/1251430. A Conceptual Model of Service Quality and its Implication for Future Research (SERVQUAL), Journal of Marketing 49:41-50. DOI: 10.2307/1251430, January 1985.

A. Parasuraman, V. Zeithaml, and L. Berry. SERVQUAL: a multiple-item scale for Measuring Consumer Perceptions of Service Quality, Journal of Retailing, vol. 64 (1) pp 12-40, January 1988.

D. Recklies. Understanding and Managing Customer Perception. The Manager.Org. Retrieved from https://www.themanager.org/2015/01/customer-perception/, January 2015.

S. Rozenberg and M.L-Tepman. Essential Ways to Adapt Your Property Management Business to Growth. Fourandhalf.com. Retrieved from https://fourandhalf.com/property-management-business-plans/, August 2020.

D.C. Sanderson and D. C. Read, "Recognizing and realizing the value of customer-focused property management", Property Management, Vol. 38 No. 5, pp. 749-764. https://doi.org/10.1108/PM-04-2020-0029, July 2020.

D.C. Sanderson, and V.M. Edwards. Determinants of satisfaction among tenants of UK Offices. Journal of Corporate Real Estate, 18 (2). pp. 102-131. ISSN 1463-001X. Retrieved from http://centaur.reading.ac.uk/51460/, 2016.

P.S. Schinder and D. R. Cooper. Business Research Methods 12th International Edition, Mc Graw Hill Education pp. 123, 148-167, 352-359, 364-371, 2014

D. Shiem-Shin Then. A proactive property management model that integrates real estate provision and facilities services management, International Journal of Strategic Property Management, 9:1, 33-42, DOI: 10.1080/1648715X.2005.9637524, February 2005. 
A. Swinscoe. What Does Customer Engagement Really https://www.forbes.com/sites/adrianswinscoe/2016/10/17/what-does-customer-engagement-reallymean/\#7e4970ee7277, October 2016.

Udemy. Service Quality Management: How to Measure and Manage It. Retrieved from https://blog.udemy.com/service-quality-management/, February 2020.

K. Venetis and P. Ghauri. Service Quality and Customer Retention: Building Long-Term Relationships. European Journal of Marketing. 38. 1577-1598. 10.1108/03090560410560254. Retrieved from https://www.researchgate.net/publication/235266692_Service_Quality_and_Customer_Retention_Building_L ong-Term_Relationships, November 2004.

H. Yang, "Quality Assessment of Property Management Personnel in Xiaogan Residential Area and its Educational Promotion Mechanism Research," 2020 International Conference on E-Commerce and Internet Technology (ECIT), Zhangjiajie, China, pp. 126-129, doi: 10.1109/ECIT50008.2020.00035. July 2020.

Z. Yu, "System Design for Property Managers' Skills Standard Based on the Psychological Contract," 2011 International Conference on Control, Automation and Systems Engineering (CASE), Singapore, 2011, pp. 13, doi: 10.1109/ICCASE.2011.5997705. August 2011.

\section{Authors Profile}

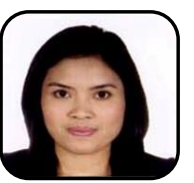

Rosario B. Gumban is a graduate of Doctor of Philosophy in Business Management at Philippine Christian University. She has been into writing and mentoring researches and presented in local and international conferences. She is a professor in Business Management and Graduate School Open Learning College at Cavite State University. She is also affiliated with numerous professional organizations - national and international.

Jessie Anne T. Demetillo is a graduate of Doctor of Philosophy in Business Management at Philippine Christian University, Philippines. She has been engaged in conducting and writing researches related to her field and currently designated as a research services coordinator of Cavite State University - Trece Martires City Campus to where she also works as a professor for more than ten years now. She is also affiliated with several professional organizations both locally and internationally.

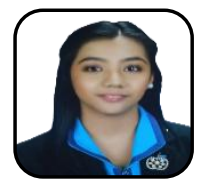

Liane Vina G. Ocampo is a graduate of Doctor of Philosophy in business management at Philippine Christian University. She is a professor in statistics, business, and economics at Cavite State University Open Learning College and a college instructor of the Entrepreneurship program of Cavite State University, Imus Campus. She has an international publication in a peer-reviewed journal in the field of econometrics and presented several research journals in local and international conferences. She is also affiliated with several academic and professional organizations. 